\title{
ナフサを原料とするガス製造装置の腐食問題"
}

\author{
（アンケート調査結果） \\ 角 野 弥 彦** \\ **日本石油瓦斯株式会社

\section{Corrosion of Naphtha Feed Gas Plant*} \\ Yahiko Kadono** \\ **Nippon Petroleum Gas Co. Ltd.
}

\section{1. まえがき}

ナフサなどを原料とする水蒸気改質装置はアンモニ アメタノール，都市ガスの製造装置として，また石油 精製の脱硫用水素製造装置として数多く使用されてい る。このプロセスは 1960 年頃, 高度成長の時代の要請 に応じた量産, 高能率の装置として実用化され, 現在も なお装置産業の主要部として操業が続けられている。

この装置は高温高圧のもとで炭化水素の水蒸気改質反 応が行われるため, 装置材料に対する要求も厳しく，材 料上，腐食上の問題がしばしば提起されている。すなわ ち, 改質炉反応管などの耐熱材料の損傷, 脱炭酸系, 熱 回収系などの機器，配管の腐食の問題などである。
そこで，当分科会はこれらの装置のどの部分でどのよ らな材料上，腐食上の問題があり，また操業各社はこれ にいかに対処し，安全な操業を続けているかを全般的に 検討するため，アンケートによる調査を行った。

この調査に当って，当分科会は昭和 50 年 4 月より会 合を重ね，アンケート項目を検討し，同年 11 月にアン ケート用紙を操業各社に発送して協力を打願いした。翌 51 年初頭，このうち約 $40 \% ， 50$ 基（水素製造装置 13 基，アンモニア製造装置 4 基，都市ガス製造装置 33 基） の装置についての回答を入手できた。

アンケートの内容は装置全体に関する広範囲なもので あったが，本報告では材料上，腐食上の問題点に絞って

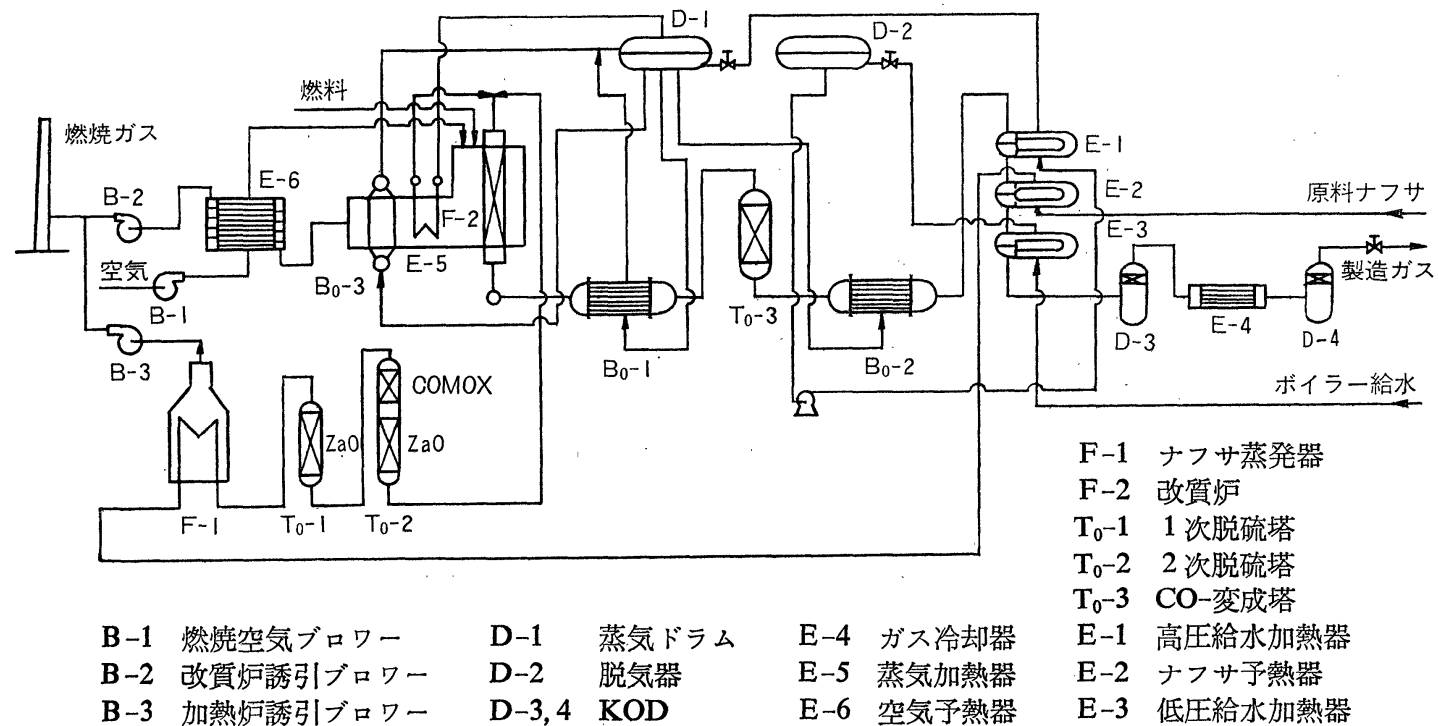

図 1 都市ガス製造装置プロセス (ICI 式)

* 第 1 専門委員会・第 2 分科会主查, 53 年春期学術講演大会で報告

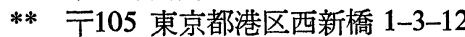




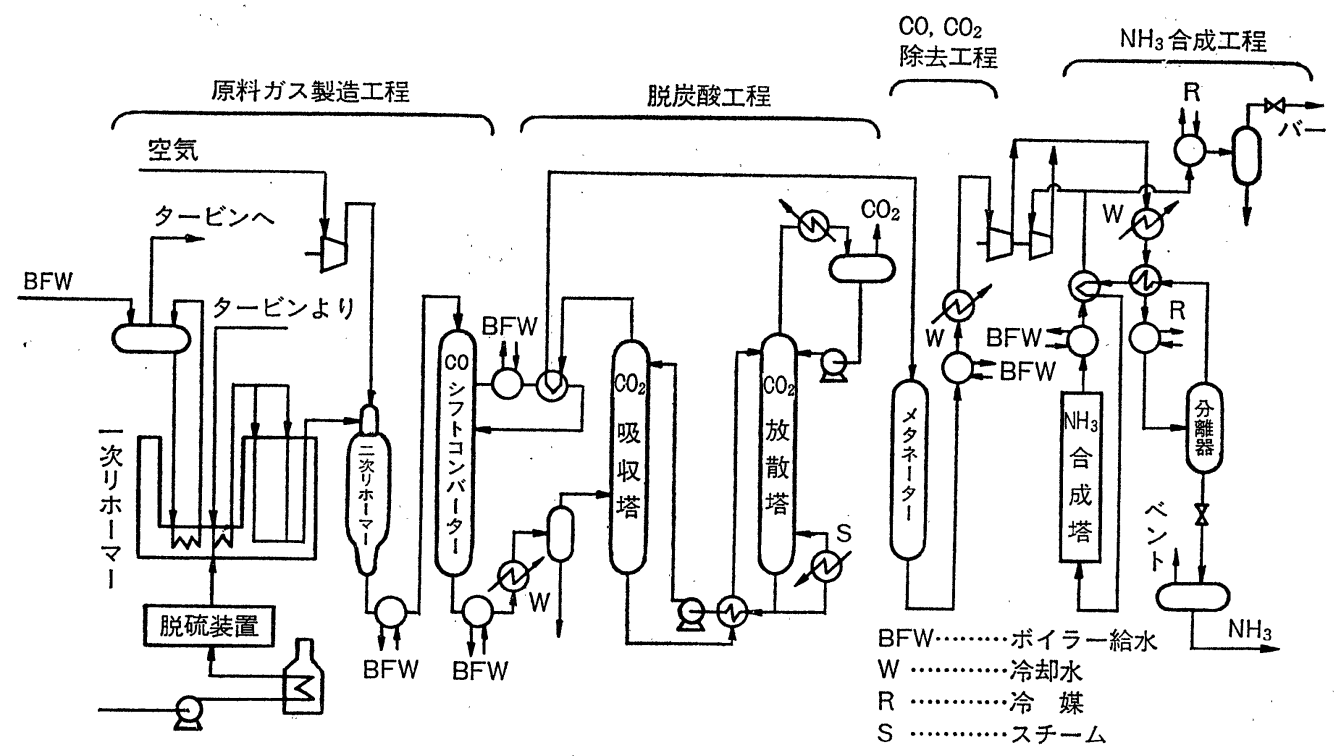

図 2 アンモニア製造装置プロセス

まとめてみた。調査の詨象とした装置は前述のごとく水 蒸気改質によるアンモニア, 都市ガス, 水素などの製造 装置であるが，各装置ともにほ注同様なプロセスを採用 しているため代表例として都市ガズ製造装置のフローシ. 一ト例を図 $1^{1)}$ に, アンモニア製造装置の例を図 $2^{2)}$ に 示す。これらのフローシート例でわかるように，各装置 は脱硫系, 改質系, $\mathrm{CO}$ 変成系, 脱炭酸系, メタネーシ ョン系の主工程とボイラ類, プロセス系熱回収部などよ り構成されており，本報告のまとめもこの区分に準じて 行ってみた。

\section{2. 脱硫系における問題点}

ナフサを原料とするガス製造装置の脱硫系では原料中 の硫黄分は最大でも $1000 \mathrm{ppm}$ ，一般には 250 300ppm のものが多い。アンケート結果によると，硫黄分による 腐食の問題はほとんど報告されていなかった。国内では 各種水素化脱硫装置の経験が豊富であり，その知見が十 分生かされていることもあろう。

脱硫系および改質系における材料上，腐食上の問題点 の有無に関するアンケート結果を表 1 に示す。

脱硫系の場合, 回答のあった 49 件のうち, “問題あ り”とした回答は 6 件であり，その内容については表 2 に示す。すなわち, 脱硫塔 (本体, トレープレート, い ずれも炭素鋼）の全面腐食 $(0.3 \sim 0.5 \mathrm{~mm} / \mathrm{yr})$ が 3 件， 加熱管の腐食が 2 件, 熱交換器が 1 件である。いずれも ナフサを原料とするガス製造装置に特有のものではな く, 硫黄分を含む流体を取扱ら装置にみられる腐食であ る。
表 1 脱硫系，および改質系に打ける材料上，腐食 上の問題点の有無

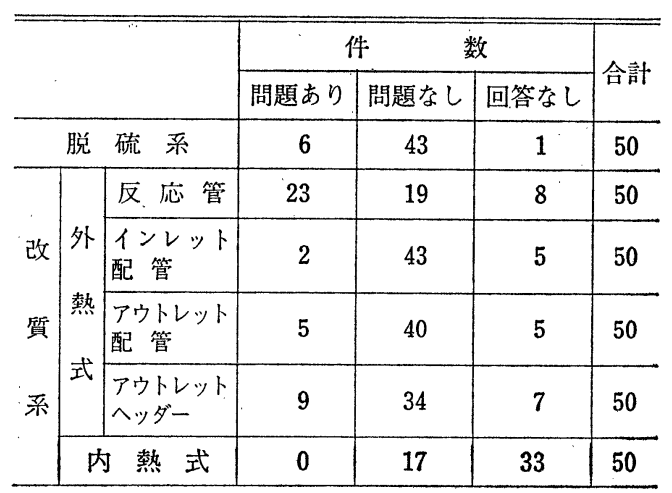

表 2 脱硫系に打ける問題点の内容 (計 6 件)

\begin{tabular}{|c|c|c|c|c|}
\hline \multicolumn{2}{|c|}{ 機器または部品名 } & 材 質 & 使用期間 & 内 \\
\hline \multirow{3}{*}{$\begin{array}{l}\text { 脱 } \\
\text { 硫 } \\
\text { 塔 }\end{array}$} & $\begin{array}{l}\text { トレープレート } \\
\text { 内 壁 }\end{array}$ & SS 41 & 10 年10ヶ月 & $\begin{array}{l}\text { 全面腐食 } \\
(0.3 \sim 0.5 \mathrm{~mm} / \mathrm{yr})\end{array}$ \\
\hline & 塔頂鏡板 & A-204 Gr. B & - & 全面腐食 \\
\hline & 内 壁 & A-204 Gr. A & 1 年 9 ヶ月 & $\begin{array}{l}\text { 全面腐食 } \\
(0.3 \mathrm{~mm} / \mathrm{yr})\end{array}$ \\
\hline \multirow{2}{*}{$\begin{array}{l}\text { 加 } \\
\text { 熱 } \\
\text { 炉 }\end{array}$} & $\begin{array}{c}\text { 加 熱 管 } \\
\text { (内面) }\end{array}$ & $\mathrm{STBA} \cdot 24$ & 5. 5年: & $\begin{array}{l}\text { 腐食およびスケ } \\
\text { 一ルよる閉塞 }\end{array}$ \\
\hline & $\begin{array}{l}\text { 加 熱 管 } \\
\text { (外面) }\end{array}$ & $\mathrm{STBA} \cdot 25$ & 5.5 年 & $\begin{array}{l}\text { 孔食状腐食 } \\
(0.2 \sim 0.3 \mathrm{~mm} / \mathrm{yr})\end{array}$ \\
\hline 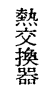 & 管のベンド部 & STB 35-S & 1年 8 ヶ月 & $\begin{array}{l}\text { 孔食状腐食 } \\
(0.6 \mathrm{~mm} / \mathrm{yr})\end{array}$ \\
\hline
\end{tabular}




\section{3. 改質系における問題点}

改質系では次式で示されるガス製造の主反応を行う工 程が含まれる。

$$
\mathrm{CmHm}+\mathrm{mH}_{2} \mathrm{O} \rightarrow \mathrm{mCO}+(\mathrm{m}+\mathrm{n} / 2) \mathrm{H}_{2}
$$

反応は大きな吸熱反応であることより，装置において は耐熱鋳鋼製の反応管にニッケル系触媒を充填し，管外 から直火により加熱して反応を進める。従って反応管は 装置中最も高温になり問題となる部分である。

\section{1 反応管の材質と使用条件}

アンケートの結果反応管の材質はすべてHK 40 (0.4C$25 \mathrm{Cr}-20 \mathrm{Ni}$ ) である。頂部フランジは SUS 321 が過半 数を占めて损り, 温度条件から, 粒界腐食に対処するた め安定化ステンレス鋼を使用していると考えるのが適当 であろう。

底部フランジ付きの構造は少なく, ほとんぞがホット ボトム型である。この場合, 都市ガス製造装置では HK 40 が圧倒的に多く, 水素製造装置の場合, インコロイ 800 が多い。

反応管の運転条件のアンケートによると, $800 \sim 930^{\circ} \mathrm{C}$, $11 \sim 34 \mathrm{Kg} / \mathrm{cm}^{2} \mathrm{G}$ の範囲で使用されている。回答のあっ た 42 件についてみると, 温度は水素製造装置が最も高 く, 圧力はアンモニア製造装置が最も高い。しかしなが ら, 都市ガス製造装置の場合, その運転の都合上, 温度 の変動が不可避であり，環境はむしろ，前 2 者に比べき びしいとみることもできる。

また回答のあった 32 件について，一年間の炉の平均 稼動時間をみると, 都市ガス製造装置が 約 6,000 時間 で, 水素製造装置の約 7,900 時間に比べ短かい。

\section{2 反応管の問題点}

反応管に淤汀問題点の有無に関するアンケート結果 は表 1 のごとくである。回答のあった 42 件のうち, 23 件が “問題あり”とし，19 件が “問題なし”としてい る。このうち “問題あり”と回答したトラブルの内容を 現象別に分類し, 表 3 亿示す。同一装置で何種類ものト ラブルがあるため, 総件数が回答数より多くなってい る。

この表より反応管の炉内部の場合はバーナの調整不 備, 触媒充填の不均一などに起因したホットスポットが 最も多く, 忓内部の損傷の過半数を占めている。一方反 応管の炉外部の場合は溶接部の応力腐食割れが過半数で あり,ついで熱疲労が多い。通常反応管は高温乾性の雾 囲気で使用されるため腐食は発生し難い。しかし炉外部 にデッドスペースがあるとコンデンセートを生じ，応力 腐食割れを発生する。中野?は应管の出口附近のデッ ドスペース部においてガス温度が露点以下となることを 確認し, $\mathrm{Cl}^{-}, \mathrm{K}^{+}$を検出している。

反応管の熱疲労は運転開始, 停止時の急激な加熱, 冷
表 3 反応管における問題点の内容

(合計 62 件)

\begin{tabular}{|c|c|c|c|c|}
\hline & $\begin{array}{l}\text { 損傷の種類 } \\
\text { または原因 }\end{array}$ & 件数 & 主な場所 & 策 \\
\hline \multirow[t]{2}{*}{ 炉 } & \begin{tabular}{|l} 
ホット \\
スポット
\end{tabular} & 10 & 母材(外面) & $\begin{array}{l}\text { 管の交換 } \\
\text { バーナー調整 } \\
\text { 触媒充填の調整. }\end{array}$ \\
\hline & クリープ & 3 & 溶 接 部 & 管の交換 \\
\hline \multirow[t]{2}{*}{ 内 } & 炭素堆積, 浸炭 & 2 & 母材(内面) & 管の交換 \\
\hline & \begin{tabular}{|l|} 
ボイド, \\
溶接欠陥
\end{tabular} & 4 & 溶 接 部 & $\begin{array}{l}\text { 管の交換, } \\
\text { 短管找入 }\end{array}$ \\
\hline 炉 & $\begin{array}{l}\text { 応力腐食割 } \\
\text { れ }\end{array}$ & 11 & 溶 接 部 & $\begin{array}{c}\text { 削除, スムーズ任 } \\
\text { 上げ, および肉盛 } \\
\text { 補修, 構造変更 } \\
\text { (ホットボトム) }\end{array}$ \\
\hline \multirow[t]{2}{*}{ 外 } & 熱疲労 & 8 & - & - \\
\hline & $\sigma$ 相析出 & 2 & - & - \\
\hline 炉 & 割 れ & 16 & $\begin{array}{l}\text { 母材, 溶接部 } \\
\text { (管内外面) }\end{array}$ & $\begin{array}{l}\text { 管の交換, } \\
\text { ス云一゙仕上げ, } \\
\text { 肉盛補修 }\end{array}$ \\
\hline & その 他 & 6 & 母 材 & 管の交換 \\
\hline
\end{tabular}

却, 運転中の負荷変動, 装入原料の不均一などにより熱 応力を発生し，これの繰返しが原因とされている。

また炉内外の区別, 原因が明示されて和らず詳細につ いては不明であるが，割れの発生の事例が 16 件と多い。 以上の損傷の内容は従来の報告 ${ }^{1 ~ 8)}$ とほぼ同じ傾向であ る。

さらに反応管に何らかの損傷が 発生した事例につい て, その発生までの使用期間は運転開始後 2 3 年の例 が最も多く, 41 件の回答のうち 28 件が $1 \sim 4$ 年以内に 生じている。

損傷対策として，溶接補修，短管插入などをする場合 の施工法についての調査結果では, 4 件の回答があり, その内容は次のごとくである。

i） 反応管底部をデッドレッグからホットボトムに変 更した (1 件)。

ii) 析出炭化物の再固溶化を目的に, 溶体化処理をし た ( 2 件)。

iii）厳重な管理のもとでグラインダーによる切削を行 った ( 1 件)。

なお, これらの補修後に再度問題が発生した, との回 答はなかったが，長時間使用した反応管の補修は二次炭 化物, $\sigma$ 相の析出してよる脆化が生じており，とくに慎 重な配慮が要求されることは当然であろう ${ }^{9}$ 。

\section{3 反応管の非破壊検查法}

反応管の非破壊検查法として，i）定修時，および ii) 運転時があるが，これらに対するアンケート結果を表 4, 表 5 に示す（回答数 42 件）。いずれも複数の検査項目を 
採用しているため，表中の件数が回答数を上回ってい る。i）については，クリープ変形量と漏洩の調査が主体 である。前者については外径, 長さ, 曲り測定により評 価し, 後者についてはカラーチェックと圧カテストによ り確認している場合が注とんどである。ii）については 温度測定があるが，光高温計を用い炉内中心部を測定し ている場合が添とんどである。

以上の非破壊検查法に対する信頼性, 問題点について の調査結果では 22 件の回答があり, このうち最も多い

表 4 定修時の検查項目（計 42 基）

\begin{tabular}{|c|c|c|}
\hline 検查項目 & 測 定方 法 & 件数 \\
\hline \multirow{4}{*}{ クリープ測定 } & 外 径 & 38 \\
\hline & 長 & 31 \\
\hline & 曲 が り & 18 \\
\hline & 外 周 & 2 \\
\hline \multirow{4}{*}{ 浸 炭 測 定 } & 膜 厚 計 & 0 \\
\hline & 顕 微 鏡 & 4 \\
\hline & フェライトメーター & 4 \\
\hline & 渦流探 傷 & 1 \\
\hline \multirow{2}{*}{ 肉 厚 測 定 } & 超 音 波 & 8 \\
\hline & 放 射 線 & 7 \\
\hline \multirow{3}{*}{ 漏洩の調查 } & カラーチェック & 38 \\
\hline & 放 射 線 & 3 \\
\hline & 圧カテスト & 36 \\
\hline \multirow{3}{*}{ そ の 他 } & 硬さ測 定 & 3 \\
\hline & 顕 微 鏡 & 3 \\
\hline & 管 内 鏡 & 4 \\
\hline
\end{tabular}

表 5 運転時の検査項目（計 42 基）

\begin{tabular}{|c|c|c|}
\hline & 検査方 法 & 件数 \\
\hline \multirow{4}{*}{ 点検方法 } & 光高温計 & 45 \\
\hline & 赤外線温度計 & 6 \\
\hline & 熱電 対 & 1 \\
\hline & 目 視 & 1 \\
\hline \multirow{4}{*}{ 点検位置 } & 炉内中心部 & 30 \\
\hline & 上中下 3 点 & 2 \\
\hline & 炉全域 & 6 \\
\hline & 炉 壁 & 1 \\
\hline \multirow{4}{*}{ 点検回数 } & 1 回/日 & 13 \\
\hline & 1 回/週 & 14 \\
\hline & 1 回/月 & 11 \\
\hline & 不定期 & 4 \\
\hline
\end{tabular}

のは，クリープ破断寿命の評価方法に関するものであ る。寸法測定による評価に対し，11 件がその信頼性に そしいため破壊検査に依存するとしている。寸法測定に より傾向が把握できるとしたのは 1 件のみである。他は 非破壞検査法全般に対する所見である。すなわち，これ ら非破壊検查は信頼性あり之回答したのが 7 件である が, これも運転状況, 過去の履歴をみて総合的に判断し ている。その他 3 件は非破壊検查全般に不安をもってい るとの回答である。

\section{4 反応管の破壊調查}

過去に反応管を交換したか否かの調查結果では延べ 57 基の装置で交換の 経験があり, その理由はほとんぞ が安全保守のための破壊調查を目的としたものである。 これら破壊調査の結果のらち，マクロ的およびミク口的 観察の結果を表 6 に示す。これらの破壊調査により割れ やボイドが発見されているようである。なお，二次炭化 物, $\sigma$ 相の析出は使用条件から当然予想されるものであ り異常な現象ではない。ボイドが発生していた，之回答 のあった 17 件のうち使用期間の明示されていた 10 件 についてみると，ほとんどが 35,000４5,000 時間でボ イドの発生を認めている。

表 6 交換した管の調査結果

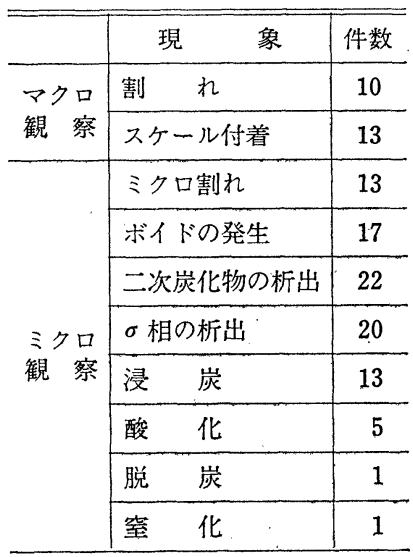

一方, マクロ的, ミク口的観察のほかに, 常温の引張 試験, 高温の引張試験, クリープ破断試験などの機械試 験も行われている。しかしながら,これらの強度は未使 用材と同等で経年変化を示さないことがあったり，また 図3に示されるクリープ破断強度のようにある程度の劣 化が認められてもその結果を安全保守に結びつける定量 的な基準がつかみ切れないなど，種々な問題点があるよ らである。このことは表 7 に示す反応管の交換時期の判 断に対する調查結果にもらかがわれる。

反応管の非破壊および破壊調査についてはアンヶート の結果や文献 ${ }^{10,11,12)}$ が示すごとく積極的に行われて拉 


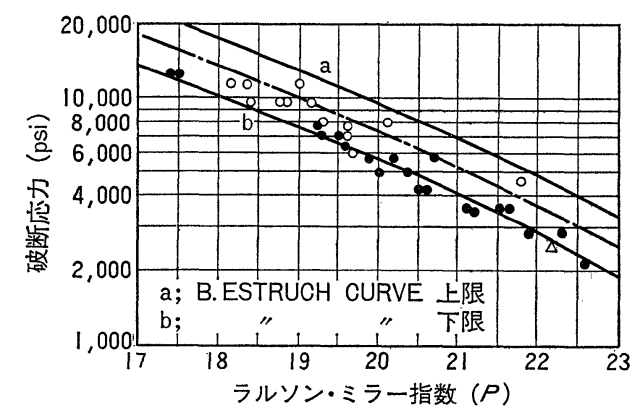

\begin{tabular}{|c|c|c|c|}
\hline \begin{tabular}{|l} 
記号 \\
\end{tabular} & プラントの種類 & 使用時間（hr） & \\
\hline $\begin{array}{l}\dot{\Delta} \\
\bullet\end{array}$ & $\begin{array}{l}\text { アンモニア } \\
\text { 水 素 } \\
\text { 都市ガス }\end{array}$ & $\begin{array}{l}22,000 \\
10,000 \sim 49,800 \\
3,000 \sim 36,000\end{array}$ & $\begin{aligned} P= & 10^{-3} \mathrm{~T}(15+\log t) \\
& T ;{ }^{\circ} \mathrm{K} \\
& t ; \mathrm{hr}\end{aligned}$ \\
\hline
\end{tabular}

図 3 長時間使用した反応管 (HK 40) のラルンン. ミラー指数とクリープ破断応力の関係

表 7 反応管交換時期の判断（回答数：41 件)

\begin{tabular}{|c|c|c|}
\hline & 交換 時期の目安 & 件数 \\
\hline 1 & $\begin{array}{l}\text { 定期的なクリープ破断試験 } \\
\text { により目安をつける }\end{array}$ & 13 \\
\hline 2 & $\begin{array}{l}\text { ボイドの発生が認められた } \\
\text { 時期 }\end{array}$ & 8 \\
\hline 3 & $\begin{array}{l}\text { 定期的な破壊試験結果と } \\
\text { S D M 時の検査結果をもと } \\
\text { に目安をつける }\end{array}$ & 3 \\
\hline 4 & $\begin{array}{l}\text { カラーチェックにより割れ } \\
\text { が認められた時点 }\end{array}$ & 1 \\
\hline 5 & 70,000時間を目安 & 1 \\
\hline 6 & $\begin{array}{l}\text { 各種機械試験を行なう予定 } \\
\text { だが現在なし }\end{array}$ & 15 \\
\hline
\end{tabular}

り, 装置の安全確保の観点からも今後その技術開発が望 まれる分野である。

3.5 インレット配管，アウトレット配管，アウトレ ットヘッターー
インレット配管，アウトレット配管およびアウトレッ トヘッダーの材料上の問題点の調査結果を表 8 に示す。 これらの配管の問題点はほとんど熱応力に起因するよう である。

\section{4. ボイラ類の問題点}

ボイラ類について腐食があるとする回答は水素製造装 置に 4 基, 都市ガス製造装置に 6 基のトラブルを経験し ており, その内訳を表 9 に示す。全 16 件の事例の具体 的内容は大部分が不詳であるが，プロセス系廃熱ボイラ が 12 件と最も多い。水質に直接関係すると思われる例 はアルカリ腐食による割れ(アルカリ脆化と考えられる) の 1 件, SUS 304 熱交換器チューブ水側の孔食 1 件, および給水ラインなどのエロージョンによる減肉の 3 件 である。その他ボイラ構造あるいは製作上に起因する問 題点であるが, シール溶接, あるいはストレングス溶接 部でのトラブルが 2 件報告されている。

ボイラーの構成材料について，材質が明記されている 回答より使用材質を列挙し表 10 に示す。プロセス系廃 熱ボイラの伝熱管材料としては STB 42 (炭素鋼管) を 用いる例から, STBA $24\left(2^{1} / 4 \mathrm{Cr}-1 \mathrm{Mo}\right.$ 鋼管) を用いる

表 9 ボイラについての材料上の問題点

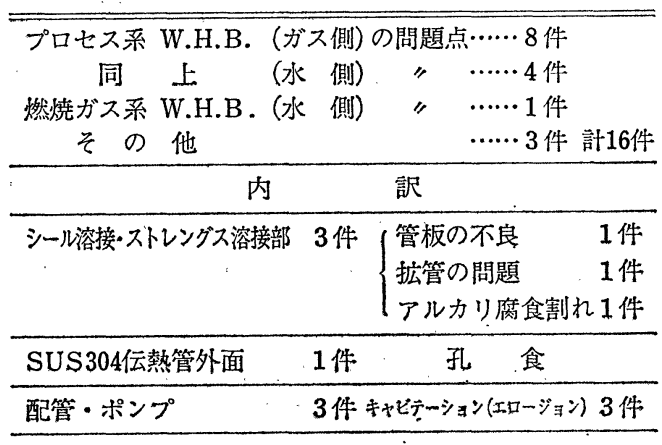

表 8 改質炉インンレットおよびアウトレット配管に执ける問題点の内容 (合計 17 件)

\begin{tabular}{|c|c|c|c|c|c|c|}
\hline & 損傷の種類 & 件数 & 質 & 主 な 場 所 & 因 & 対 \\
\hline \multirow{3}{*}{$\begin{array}{l}\text { インレット } \\
\text { 配 管 }\end{array}$} & 粒界腐食 & 1 & \multirow{3}{*}{ SUS 304} & - & 材料欠陷 & - \\
\hline & 孔 食 & 1 & & - & 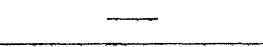 & - \\
\hline & 高温腐食 & 1 & & フランジ & 焼付け防止材 & 耐熱用ペーストの採用 \\
\hline \multirow{2}{*}{$\begin{array}{l}\text { アウトレット } \\
\text { 配 管 }\end{array}$} & 割 れ & 4 & \multirow{2}{*}{$\begin{array}{l}\text { インコロイ合金 } \\
-800\end{array}$} & $\begin{array}{l}\text { ピッグテール, ボス, } \\
\text { アウトレットヘッダー } \\
\text { 等の溶接部 }\end{array}$ & 熱 応 力 & $\begin{array}{l}\text { 構造変更 (たとえばル } \\
\text { 一プ改良) } \\
\text { 削除, 肉盛補修 }\end{array}$ \\
\hline & 粒界酸化 & 1 & & - & - & 取 替 え \\
\hline $\begin{array}{l}\text { アウトレット } \\
\text { ヘッダー }\end{array}$ & 割 & 9 & $\begin{array}{l}\text { インコロイ合金 } \\
-800(4) \\
\mathrm{HK}-40(4) \\
\mathrm{HK}-30(1) \\
\end{array}$ & $\begin{array}{l}\text { ピッグテール, アウト } \\
\text { レットヘッダーの溶接 } \\
\text { 部, コレクターとボス } \\
\text { の溶接部 }\end{array}$ & $\begin{array}{l}\text { 熱応力十材質の勒性低 } \\
\text { 下 } \\
\text { 溶接欠陥十熱応力 } \\
\text { 材質不良, 溶接欠陥 } \\
\end{array}$ & $\begin{array}{l}\text { 材質変更 } \\
\text { (HKー40をインコロイ } \\
\text { 合金 } 800 \text { に取替え) }\end{array}$ \\
\hline
\end{tabular}


表 10 ボイラ使用鋼材（材質明記のものより）

\begin{tabular}{l}
\hline 件数 \\
\hline
\end{tabular}

例むで，種々である。ただし表中の使用温度は金属表面 温度とプロセス流体温度とを混乱している点があり, 設 計ベースではとートバランスを計算し金属表面温度, お。 よびプロセス側の水素量を勘案して材質を決定してい る。この点については然焼ガス系廃熱ボイラに扔いても 同様であり，伀熱管材料に $343^{\circ} \mathrm{C}$ で STBA 24 を用い ている所もあれば, $730^{\circ} \mathrm{C} て ゙ S T B ~ 42$ を使用していると いう一見矛盾した結果となっている。SUS 304 を用い ている例に和いては, 原因は明瞭ではないが水側より孔 食を生じ, SUS 316L に変更しているとの回答がよせら れている。

API の調査 ('68)4) は水質管理とキャリオーバーによ るトラブルの関係を述べて拈り, 水質が不良の場合は当 然ボイラに和けるトラブルの原因となるが，同時に改質 系の反応管材料, ヘッダー材料などのトラブルをひき起 こす例が示されている。また高圧ニニットでは完全゙に demineralize した水質を用いる傾向にあるという。同 じく API の調査 ('72) ${ }^{13)}$ によると, 高濃度固形分を含 有するスチームを用いた装置がキャリオーバにより反応 管の破損に至ったと報告している。本アンケートではキ
ヤリオーバーによる改質系での問題は報告されていな い。

流出カリによるトラブルとして前記 API の調査など でナフサ改質炉のステンレス鋼, あるいは高ニッケル合 金の応力腐食割れの原因になる事が種々報告されてい る。本アンケートによるとカリによる腐食は 2 件の回答 があるが，いずれも上記トラブル状況とは多少趣きが異 なっていて炭素鋼系の全面腐食的な状況について報告さ れているのみである。

\section{CO 変成系の問題点}

$\mathrm{CO}$ 变成系での腐食例は表 11 に示すごとく 3 件のみ 報告されているが，いずれも炭素鋼の炭酸による腐食で ある。いずれの場合も保温などの比較的簡単な变更によ り低温コンデンセートを生じない対策をとれば良いよう に見受けられる。

$\mathrm{CO}$ 变成系に用いられる材質を明示された例につき列 挙すると表 12 のごとくであり, 高温変成塔では温度, 圧力ともにあまり差がないにもかかわらず炭素鋼より A 387 B (1 Cr-1/2 Mo 鋼) まで使用されている。一方, 
表 $11 \mathrm{CO}$ 変成系での腐食例

\begin{tabular}{|c|c|c|c|c|c|c|c|}
\hline \multirow{2}{*}{ 腐 食 位 置 } & \multirow{2}{*}{ 材 質 } & \multicolumn{2}{|c|}{ 使 用 条 件 } & \multirow{2}{*}{ 使用期間 } & \multirow{2}{*}{ 状 } & \multirow{2}{*}{ 原因 } & \multirow{2}{*}{ 対 策 処 置 } \\
\hline & & 温度 $\left({ }^{\circ} \mathrm{C}\right)$ & 圧力 $\left(\mathrm{kg} / \mathrm{cm}^{2}\right)$ & & & & \\
\hline 配＼cjkstart管（温水管） & 炭 素 鋼 & 80 & $3 \sim 4$ & 10年 & 孔 & 炭酸 & $\begin{array}{c}\text { 熱温水温度の上昇 } \\
\left(\mathrm{CO}_{2} \text { 減少 }\right)\end{array}$ \\
\hline 高温変成塔(ノズル,フランジ) & $\begin{array}{c}\mathrm{A}-182 \\
\mathrm{~F}-1\end{array}$ & 374 & 21.8 & 5 年 6 月 & $\begin{array}{l}\text { フランジORJ溝 } \\
\text { の腐食 }\end{array}$ & 炭酸 & フランジ交換, 外面保温 \\
\hline 低温変成塔 $\left(\begin{array}{l}\text { ユーテイリテイ } \\
コ \text { ネション }\end{array}\right)$ & STPG38 & 217 & 18 & 3 年 4 月 & ノズル内面腐食 & 炭酸 & ノズル交換, 外面保温 \\
\hline
\end{tabular}

表 12 変成塔等での使用鎙材（材質明記のものより）

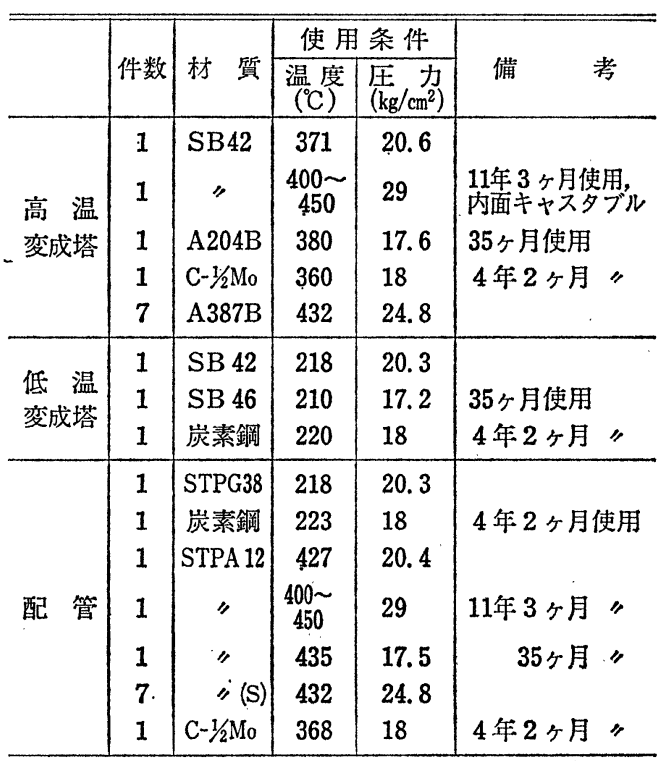

低温変成塔ではほぼすべて炭素鋼が用いられている。

\section{6. プロセス系熱回収部の問題点}

プロセス系熱回収部での腐食上の問題としては 45 件 が回答されている。その内容の明記されている事例の内 訳を表 13 に示したが，半数以上を熱交換器が占めてい る。内容的には SUS 304 系の応力腐食割れが 33 件と非 常に多く，次いで炭素鋼を用いた場合の炭酸による局部 腐食，あるいは全面腐食の 5 件となって扣り，它の他 SUS 434 のトラブルが 2 件などとなっている。

すなわちこの熱回収部は CO 変成系之同様, 炭酸によ る炭素鋼の腐食が生じる部分で, その激しさは $10 \mathrm{~mm} /$ yr にも達する事例が報告されている事からも推量でき る。しかしこれをただちに SUS 304 系のオーステナイ トステンレス鋼に代替すると今度は応力鹰食割れの危険 性が現われてくることを示している。この応力腐食割れ は毎年補修する例や， 1 週間でトラブルが発生した例が ありきわめて苛酷な環境であることが知られる。したが

表 13 プロセス系熱回収部での材料上の問題点

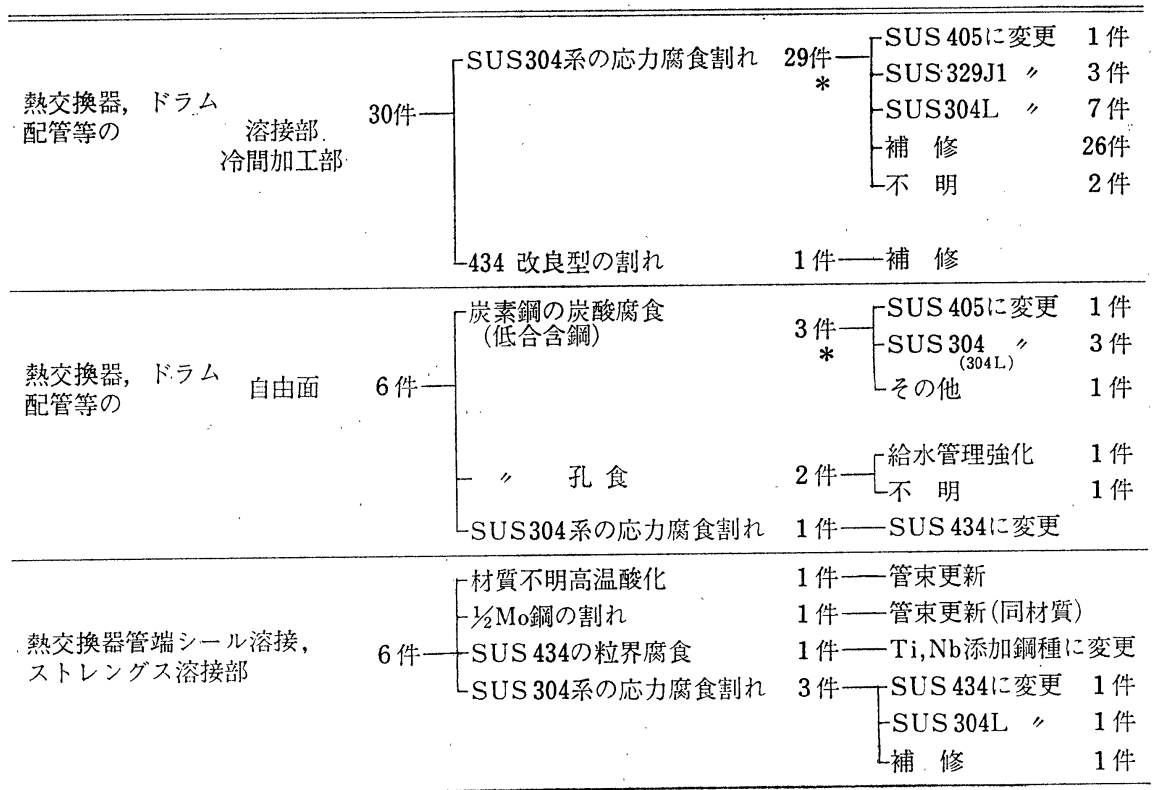

（*）同時に数種の改良变更をしている例があるため件数は一致していない。 
ってこれらのトラブルを避けるために SUS 405, 434 な ぞのフェライト系，あるいは SUS $329 \mathrm{~J}_{1}$ のような二相 系のステンレス鋼を使用することになる。一方その実用 化に当っては加工上の制約もあり充分に効果が発揮され ていない面も見られるが，材料開発の一例も報告されて

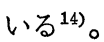

なお 304 系ステンレス鋼の応力腐食割れの原因である が，これが都市ガス製造装置に多発しているが，割れ発 生の条件に何らかの相関があるのかは不明である。ただ し $\mathrm{CO}$ 変成が一段のみで圧力 $30 \mathrm{~kg} / \mathrm{cm}^{2} \mathrm{G}$, 熱交換器の 入口温度 $200^{\circ} \mathrm{C}$ 位の場合に多い上うである。このよう な入口温度が高い時に割れが生じやすいのであろうが， いくつかのアンケート回答中に述ベられている高温炭酸 水による割れか，あるいは一部のプラントで考慮されて いる $\mathrm{K}^{+}$または $\mathrm{Cl}^{-}$によるもかは現在のところ確定さ れた割れ機構として把握されていない。

$\mathrm{CO}-\mathrm{CO}_{2}-\mathrm{H}_{2} \mathrm{O}$ 環境に括いて, 炭素鋼は応力腐食割れ を発生することを小若ら ${ }^{15)}$ が報告している。この実験に よれば高温下ではないが $9 \% \mathrm{Cr}$ 以上の高クローム鋼, および $18 \mathrm{Cr}-8 \mathrm{Ni}$ オーステナイトステンレス鋼は割れ を生じないとされている。しかし一方阿部ら ${ }^{16)}$ の実験で は同様な環境の高温条件に打いて，305 系ステンレス鋼 に割れが再現することを確認している。

またアンケート中に K+による割れと判断している回 答があるが，これは触媒からの流出カリによるものと考 壳らる。

なお，SUS 304 の応力腐食割れ対策に 304L，の代替 材を回答している例があるが，熱影響による炭化物の析

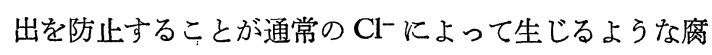
食割れの対策になるとは考光難い。

\section{7. 脱炭酸系の問題点}

脱炭酸系での腐食問題の内訳を分類したものを表 14 に示す。トラブルが生じる場所は比較的全体にわたって 散在しているょうである。

内容としては炭素鋼部分の炭酸腐食扣よび孔食が 9 件, 同じ炭素鋼でのエロージョンが 7 件, ポンプでのス テンレス鋳物のエロージョン（あるいはキャビテーショ ン) が 4 件と多い。

脱炭酸液では炭素鋼, 高張力鋼などに応力腐食割れを 生じる事があり応力除去焼鈍を施工している装置が大部 分である。再生塔, 熱交換器などに応力除去焼鈍を施工 してあるにもかかわらず応力腐食割れを生じている例が 数件みられる。しかし正規の熱処理さ六行われていれ ば，たとえこれらの溶液が応力腐食割れをひき起こする のであるとしても割れることは無いと考えられる。これ ら脱炭酸溶液が応力腐食割れを生じる原因になりらるか
表 14 脱炭酸系に打汀る材料上の問題点

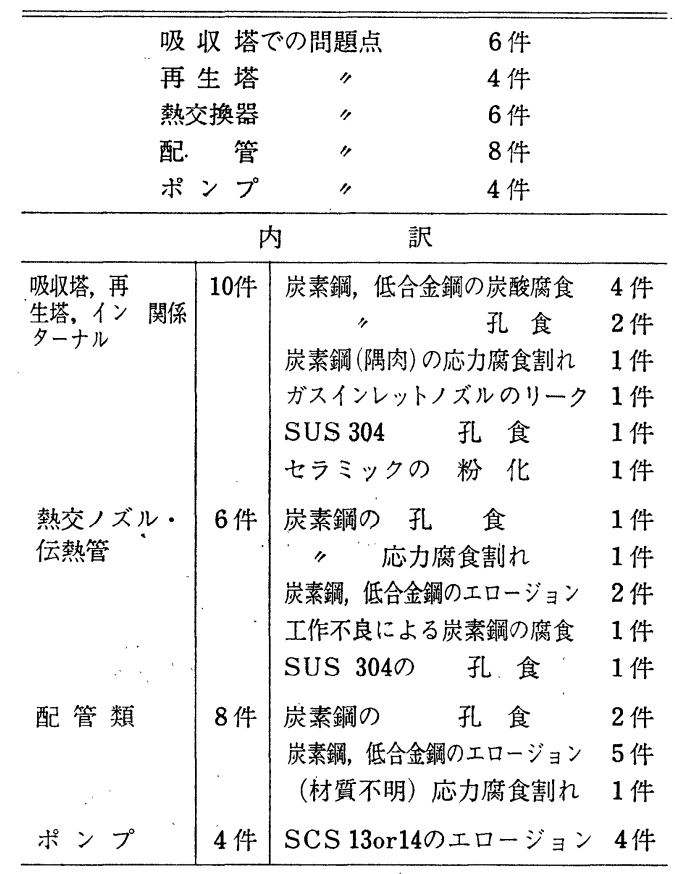

ぞうかについては不明な点が多い、17)。

炭素鋼はもとより SUS 304 に捣いても腐食の原因と して防食コーティングの不良, あるいは防食皮膜の不足 を指摘している例が数件みられるが，熱炭酸カリ溶液に 種々のインヒビターとしての作用をする物質を添加して いる溶液では, これらの物質濃度, および $\mathrm{CO}_{2}$ 含有量 を常時監視する必要がある。

またりボイラーに技いて，ウェアプレート(せき板)が 不良なため, 液レベルが保てなくなり管板面 (S25C) が 局部減肉している例があるように，リボイラーにおいて は常に伝熱管管束全体が充分に液中に浸漬している必要 があり, 同時に加熱水蒸気温度のコントロールが重要な ポイントである。な打吸収塔入口の炭酸腐食の場合, 入 ロガス温度が $100 \sim 138^{\circ} \mathrm{C}$ とやや高目の場合に多く発生 している。

使用材質について明記されたものを表 15 亿をとめた。 吸収塔, 再生塔いずれも SB 材が主であるが SUS 材の 部分当て板を施すものが比較的多く，これは遊離炭酸に よる腐食を防止するためであろう。熱交換器の伝熱管材 料としては炭素鋼 SUS 304 系などが使われている。

\section{9. メタネーション系, その他の機器の問題点}

メタネーション亲に打いては腐食ありとする回答は無 かった。装置材料の腐食とは特に関係はないが，この系 ではニッケル, カルボニル反応があり, その有毒性拉よ び触媒中のニッケルの消耗なぞの問題がある。CO が存 
表 15 脱炭酸系使用鋼材（材質明記のものより）

\begin{tabular}{|c|c|c|c|c|c|c|}
\hline & \multirow[b]{2}{*}{ 件数 } & \multirow[b]{2}{*}{ 材質 } & \multicolumn{2}{|c|}{ 使 用 条 件 } & \multirow[b]{2}{*}{ 使 用 状 況 } & \multirow[b]{2}{*}{ 対 策 処 置 } \\
\hline & & & ${ }^{\text {温 }}\left({ }^{\circ} \mathrm{C}\right)^{\text {度 }}$ & $\begin{array}{l}\text { 压 吕 } \\
\left(\mathrm{kg} / \mathrm{cm}^{2}\right)\end{array}$ & & \\
\hline 吸 収 塔 & $\begin{array}{l}2 \\
1 \\
1 \\
1 \\
1 \\
1\end{array}$ & $\begin{array}{l}\text { SB42 } 1 \text { 件 } \\
\text { SB46 } \\
\quad \text { " (- 部 } 304 \mathrm{~L}) \\
\text { SM41B } \\
\text { SM50 } \\
\text { FTW60 }\end{array}$ & $\begin{array}{r}130 \\
80 \\
113 / 70 \\
100 / 90 \\
138 \\
100\end{array}$ & $\begin{array}{l}19.2 \\
28 \\
16.7 \\
15 \\
28 \\
30\end{array}$ & $\begin{array}{c}\text { 防食皮膜の不良による孔食 } \\
\text { 炭酸による局部減肉 } \\
\text { " " }\end{array}$ & $\begin{array}{l}\text { 肉盛補修, 熱処理 } \\
\text { 耐食材ライニング } \\
\text { SUS材 " }\end{array}$ \\
\hline $\begin{array}{l}\text { 再 生 塔 } \\
\text { インタナール }\end{array}$ & $\begin{array}{l}1 \\
1 \\
1 \\
1 \\
1 \\
1\end{array}$ & $\begin{array}{l}\text { SB42 } \\
\text { SB42+SS41 } \\
\text { SB42(一部 } 304 \\
\text { Glad }) \\
\text { SB42(" "304L }) \\
\quad \text { Clad } \\
\text { SUS304 }\end{array}$ & $\begin{array}{c}123 \\
118 / 110 \\
\\
103 \\
113 / 102 \\
110\end{array}$ & $\begin{array}{l}0.35 \\
0.6 \\
1 \\
1.05 \\
0.2 \\
0.1\end{array}$ & $\begin{array}{l}\text { 孔 食 } \\
\text { サポートリング溶接部の割れ } \\
\text { 防食皮膜の不良による孔食 }\end{array}$ & $\begin{array}{l}\text { SUS 29ライニング } \\
\text { 更 新 } \\
\text { 防食浻投入取替 }\end{array}$ \\
\hline $\begin{array}{r}\text { 熱交 換 器 } \\
\text { 胴 体 } \\
\text { 管 板 } \\
\text { 伝熱管 }\end{array}$ & $\begin{array}{l}1 \\
4 \\
1 \\
1 \\
1 \\
1 \\
1 \\
1\end{array}$ & \begin{tabular}{|l|} 
SS41 \\
SB42 \\
S25C \\
S25C (SUS Clad) \\
STB30 \\
STPG38 \\
SUS304 \\
SUS304L
\end{tabular} & $\begin{array}{c}110 \\
110 \\
100 / 80 \\
\text { 冷却水 } 3.5 \\
110 \\
113\end{array}$ & $\begin{array}{l}0.2 \\
0.4 \\
2 / 3 \\
2 \\
0.4 \\
0.35\end{array}$ & $\begin{array}{l}\text { シェル側ウェア・プレート不良 } \\
\text { による局部減肉 } \\
\text { 防食皮膜の不良による孔食 } \\
\text { 冷却水による孔食 } \\
\text { 防食皮膜の不良による孔食 }\end{array}$ & $\begin{array}{l}\text { SUS 304Lに変更 } \\
\text { ウェアプレート更新 } \\
\text { 防食材投入 SUS 304Lに変更 } \\
\text { チューブ交換 } \\
\text { 防食剤投入 SUS304Lに変更 }\end{array}$ \\
\hline 配 & $\begin{array}{l}1 \\
1 \\
1 \\
1 \\
1 \\
1 \\
3 \\
1 \\
1 \\
1\end{array}$ & $\begin{array}{l}\text { SGP } \\
" \\
\text { STPG38 } \\
" \\
" \\
\text { 炭素鋼 } \\
" \\
\text { SUS } 304 \\
\text { SUS316 }\end{array}$ & $\begin{array}{r}110 \\
110 \\
65 \\
114 \\
\\
110 \\
104\end{array}$ & $\begin{array}{l}1 \\
0.4 \\
17.5 \\
28 \\
20 \\
29\end{array}$ & $\begin{array}{l}\text { 応力腐食割れ } \\
\text { 防食皮膜の不良による孔食 } \\
\text { 崖酸あるいはエロージョン } \\
\text { による局部減肉 } \\
\text { エロージョン } \\
\text { エロージョン } \\
\text { インヒビター濃度低下による } \\
\text { 穿孔 }\end{array}$ & $\begin{array}{l}\text { STPY41に変更 } \\
\text { 撤 去 } \\
\text { SUS 材に変更 } \\
\text { SUS304に変更 } \\
\text { インヒビター濃度上昇 }\end{array}$ \\
\hline ポ ン $7^{\circ}$ & $\begin{array}{l}1 \\
1 \\
1 \\
1 \\
1\end{array}$ & $\begin{array}{c}\text { SCS } 13 \\
\text { SCS } 14 \\
" \\
" \\
\text { SCS }\end{array}$ & $\begin{array}{r}110 \\
138 \\
114 \\
102 \\
75\end{array}$ & $\begin{array}{l}1.2 / 30 \\
28 \\
28 \\
29 \\
40\end{array}$ & $\begin{array}{c}\text { エロージョン } \\
\text { " } \\
\text { " } \\
\text { " }\end{array}$ & $\begin{array}{l}\text { 更新予定 } \\
\text { 更 新 } \\
\text { 溶接肉盛 } \\
\text { SCS 24に変更 }\end{array}$ \\
\hline
\end{tabular}

在し比較的低温 $\left(70 \sim 150^{\circ} \mathrm{C}\right)$ でこの反応が生じるとさ れているが，運転方法などで解決されているものと思わ れる。

その他の機器での腐食事例として 2 件の回答があった が， 2 件ともコンデンセートセパレータのトラブルであ る。1 件は SB 材が何らかの要因で炭酸腐食を生じたも のとみられ SUS 304L の部分ライニングに変更してい る。他の 1 件はステンレス鋼ライニングがコンデンセー トにより剝離，割れが生じたものであり施工方法などの 良否による部分が多いと思われる。

\section{0. あとがき}

炭化水素の水蒸気改質装置の材料上, 腐食上の問題に ついてアンケート調査から本報告をまとめることができ た。概略ではあるが，この種の装置の全般的な問題点を 摑まえることでいささかなりと関係者各位の御参考にな れば幸である。

最後に, 御多用中にもかかわらずアンケートに御協力 いただいた操業各社，および直接回答に御記入いただい た御担当の方々に厚く㧍礼を申し上げます。 


\section{文献}

1）真下 進: 高圧ガス, 13, No. 5, 41 (1976).

2) 岡 光: 高圧ガス, 13, No. 6, 29 (1976).

3）渡辺竹春, 佐藤綱一：高圧ガス, 13, No. 4, 31 (1976).

4) A. R. Ciuffreda, B. E. Hopkinson: "Survey of Corrosion Problems in Reformer Hydrogen Plants" 33rd Midyear Meeting of API, Division of Refining May 15, 1968.

5) L. A. Zeis, E. Heinz: Chem. Eng. Progr. 66 (1970).

6) A. R. Ciuffreda, B. N. Green: Hydrocarbon Processing, No. 5, 113 (1970).

7) 中野知敬: 化学装置, 14, No. 12, 12 (1972).

8) E. L. Creamer: Chem. Eng. Progr., 70, No. 8 69 (1974).

9) C. H. Voelker, L. A. Zeis: Hydrocarbon Processing, No. 4, 121 (1972).

10) A. Fertillio, B. Princip: Hydrocarbon Processing, No. 9, 174 (1975).

11）笠原晃明：日本瓦斯協会誌, 29, No, 8, 4 (1976).
12）武川哲也, 石丸 裕: 「スチームリフォーミン グ用反応管材料の経年変化について」, 化学工学 協会第 42 年講演要旨集, 1977 年 4 月。

13) A. R. Ciuffreda, B. N. Green: "Survey of Materials and Corrosion Experience in Hydrogen Plants" 37th Midyear Meeting of API, Division of Refining, May. 10, 1972.

14）沢田忠雄，鈴木輝夫，横尾幸雄：「スチームリフ ォーミングプラント熱回取系の材料について」, 腐食防食協会 ’75 春期大会講演要旨集 p. 168.

15）小若正倫, 永田三郎：防食技術, 21, No. 4,165 (1972).

16）阿部信彦, 佐藤健二, 賀川直彦: 圧力技術, 15, No. 5, 46 (1977).

17) 内藤勝之, 橋本哲之祐, 木原建彦：石油学会誌, 14, No. 9, 672 (1971).

委 員

内藤勝之, 河合卓雄, 木原建彦, 藤咲 衛, 沢田忠雄 細川展男, 河西孝昭, 高田耕一郎, 杉谷恒雄, 岡 光, 秋山哲郎, 䲨巣 斌, 真下 進, 角野弥彦主査。 